\title{
Forced degradation studies to identify organic impurities in pharmaceuticals: a Brazilian perspective
}

\author{
Fernanda Fernandes Farias ${ }^{1 *}$ (1), Valéria Adriana Pereira Martins ${ }^{1}$ (D), Helena Miyoco Yano ${ }^{1}$ (D), \\ Luz Marina Trujillo ${ }^{1}$ (D), Ernani Pinto ${ }^{2,3}$ (1) \\ ${ }^{1}$ Núcleo de Ensaios Físicos e Químicos em Medicamentos, Centro de Medicamentos, Cosméticos e Saneantes, Instituto Adolfo \\ Lutz (IAL), São Paulo, SP, Brasil \\ ${ }^{2}$ Departamento de Análises Clínicas e Toxicológicas, Faculdade de Ciências Farmacêuticas, Universidade de São Paulo (USP), \\ São Paulo, SP, Brasil \\ ${ }^{3}$ Divisão de Funcionamento de Ecossistemas Tropicais, Centro de Energia Nuclear na Agricultura, Universidade de São Paulo \\ (USP), Piracicaba, SP, Brasil \\ *Corresponding author: farmafernanda@gmail.com
}

\begin{abstract}
Objective: The aim of this study was to highlight and sediment the necessary steps to be followed while conducting forced degradation studies to identify degradation products and to describe the Brazilian and international regulations associated with degradation studies of drugs and drug products. Methods: This review was conducted based on the Brazilian guidance tools as RDC 53/2015, Guide 4 and Question and Answer resource; references used as international guides; and articles in the field of degradation product analyses. Results: Characterization of the impurity profile for a substance, and development of indicative stability methods are essential criteria for compliance with current legislation, and address a legitimate health concern. As this matter falls under the purview of recently published regulation, many doubts remain regarding methods of conducting studies of forced degradation, and development of methods indicative of stability. Analytical conditions predict degradation after exposing them to thermal, humid, acidic, basic, oxidation, photolytic, and metal ion conditions. Conclusions: Although RDC 53/2015 outlines the parameters of degradation, the analytical conditions are not specified, as well as in other international standards. A well-designed forced degradation study is key to obtaining a good stability indicating method with peak purity and mass balance.
\end{abstract}

Keywords: Drug Stability. Legislation. Drug. Brazilian Health Surveillance Agency. Health Surveillance of Products.

\section{How to cite}

Farias FF, Martins VAP, Yano HM, Trujillo LM, Pinto E. Forced degradation studies to identify organic impurities in pharmaceuticals: a Brazilian perspective. Rev Ciênc Farm Básica Apl.

2021;42;e729. https://doi.org/10.4322/2179-443X.0729

\section{INTRODUCTION}

The presence of impurities in drugs and/or drug products has been known to manufacturers for a long time. However, concerns regarding potential toxicity have intensified following the identification of impurities as the root cause of numerous adverse events in patients. In Brazil,

Financial support: This work was supported by the University of São Paulo Foundation (FUSP) (Project\#1979) through a publication fee. Conflicts of interest: The authors declare that there are no conflicts of interest.

The study was carried out at Adolfo Lutz Institute and University of São Paulo. São Paulo, SP. This work was carried out based on the master's project revision of USP student Fernanda Fernandes Farias, with professor Ernani Pinto. Received on March 10, 2021. Accepted on May 18, 2021. 
Resolution of Executive Board (RDC) No. 53/2015 of the Brazilian National Health Surveillance Agency (ANVISA) approving guidelines based on the International Conference on Harmonization (ICH) recommendations was legislated. These guidelines established parameters for reporting, identification, and qualification of degradation products formed during the shelf-life of a drug product. In their entirety, the established guidelines demanded more selective and specific analytical methods that would be capable of identifying low concentrations of impurities, thus ensuring the safety of dispensed drug products in the regulated pharmaceutical sector ${ }^{1,2}$.

Currently, the regulatory guidelines regarding the experimental and analytical conditions that should be employed during forced degradation studies are very general, which in turn generalize the development of stability indicating methods ${ }^{3,4}$. Impurity profile characterization of a substance and the development of a stability indicating method are necessary criteria for complying with current regulations, as the presence of impurities in drug products has become a public health problem. Drug instability generates certain degradation products that may cause therapeutic inadequacy or potential toxic effects in the patient ${ }^{5}$.

Establishing exposure limits to impurities without any risk to human health has become a global concern because of the number of serious adverse events experienced around the world due to the presence of impurities in drug products, with some events having resulted in fatal outcomes ${ }^{6}$.

In view of this information, this review aims to highlight and sediment the necessary steps to be followed while conducting forced degradation studies to identify degradation products in drugs or drug products.

\section{ADVERSE EVENTS RELATED TO IMPURITIES IN DRUG PRODUCTS}

In 1954, Germany developed thalidomide which was intended to treat anxiety, tension, and nausea, and was well tolerated in pregnancy at the time. Four years later, the drug was released worldwide in 146 countries, with few exceptions, such as the United States of America (USA). The US Food and Drug Administration (FDA) identified the need for further testing due to the occurrence of peripheral neuritis and thyroid changes in clinical trial participants. After three years, it was found that the use of thalidomide in pregnancy caused severe adverse effects in newborns, such as phocomelia, a syndrome characterized by the shortening of the limbs close to the trunk of the fetus, making them similar to those of a seal ${ }^{7}$.

The side effects of thalidomide were associated with the chiral impurity of its isomer. Therapeutic activity occurs due to the $R-\left(^{+}\right)$enantiomer, however, the $S-(+)$ enantiomer is teratogenic. When this discovery was made, thalidomide had already caused malformations in more than 10,000 newborns, which led to several regulatory agencies banning its use. Nevertheless, in 1965, thalidomide was found to be beneficial in the treatment of leprosy, causing it to be reintroduced into the market after the enantiomeric impurity had been removed ${ }^{7,8}$.

The association between consuming expired tetracycline and developing Fanconi syndrome was established and published through a case report in 1963. This syndrome is characterized by a reabsorption disorder in the proximal renal tubulopathy of glucose, amino acids, phosphates, bicarbonate, and potassium, in addition to tubular proteinuria, deficient urinary concentration, and disorders in the acidification process. Among the symptoms presented by patients were weakness and anorexia, followed by nausea and profuse vomiting ${ }^{9}$. Two anhydrotetracycline and 4-epi anhydrotetracycline degradation products have already proven to be toxic and are associated with deleterious effects in expired antimicrobials ${ }^{10}$.

In 1989, there were numerous deaths caused by an autoimmune disease, which increased blood production of eosinophils and caused myalgia. This condition was associated with the consumption of food supplements containing L-tryptophan. A Japanese industry at the time modified the bacteria used to produce L-tryptophan, causing more than 1,500 cases of eosinophilia-myalgia syndrome (SGA) and at least 37 deaths. This case was associated with the presence of the impurity L-5-hydroxytryptophan. However, even before 1989, other cases of SGA had been reported by people who had consumed L-tryptophan from different brands of supplements. Based on epidemiological data, other impurities, including 1,1'-ethylidenebis, could also be related to SGA induction, or a combination thereof ${ }^{11}$. 
Between 2007 and 2008, several cases of allergic reactions and deaths in Missouri (USA) associated with the use of heparin were identified. It was found that the heparin products contained the contaminant named supersulfated chondroitin sulfate that caused hypotension, nausea, and shortness of breath within 30 min post administration, which was fatal in some cases. At the time, the quality control tests used did not indicate stability of the drug and were therefore unable to differentiate heparin from its impurity. However, the FDA implemented changes in the reference standards for heparin and developed a new analytical method that is capable of identifying impurities ${ }^{6,12}$.

In mid-2018, the European Medicines Agency (EMA) identified the presence of the impurity $\mathrm{N}$-nitrosodimethylamine (NDMA) in valsartan, a drug product produced by a Chinese pharmaceutical company. Consequently, EMA started to investigate this impurity in other drug candidates of the same class. They detected other nitrosamines such as $N$ nitrosodiethylamine (NDEA), N-nitrosodiisopropylamine (NDIPA), and $N$-nitrosomethylnbutylamine (NMBA) in several other manufacturers. The findings of this investigation prompted ANVISA to start examining whether drugs in the "sartan" class were contaminated. In total, 14 suspensions were suspended one of the three inputs, losartan, valsartan, or irbesartan, from ten international manufacturers ${ }^{13}$.

Nitrosamines are classified as probable or potential carcinogens for humans. European authorities estimated that the risk of developing cancer from the continuous consumption of these compounds is $0.00017 \%$, that is, for every 6,000 people who took a drug product contaminated with a nitrosamine at its maximum dose, every day for 5 years in a row, 1 (one) could develop cancer. In January 2019, nitrosamines were detected in ranitidine, a drug intended for the treatment of stomach diseases ${ }^{14}$.

Over the years, these cases have led to decreased confidence among the general population regarding the production of safe medicinal products. In order to prevent adverse events caused by drug impurities, regulatory guidelines are increasing the requirements for development and validation of selective and specific analytical methods that are able to properly demonstrate the safety of drug products dispensed to the public.

\section{BRAZILIAN REGULATIONS ASSOCIATED WITH DEGRADATION STUDIES OF DRUGS AND DRUG PRODUCTS}

The publication of RDC No. 58/2013 made it mandatory for the reporting, identification, and qualification of degradation products in dosage forms with synthetic and semi-synthetic $A P{ }^{15}$. Before this Resolution could be implemented, it was revoked and replaced by RDC No. $53 / 2015$ ". The objective of this "new" Resolution was to encourage the distribution and commercialization of drug products that were safe, met certain quality standards, and efficacious. Together with RDC No. 53/2015, Guide No. 04/2015 was published, which was a guideline for conducting forced degradation studies and developing and validating stability indicating methods ${ }^{2}$.

Thereafter, on October 4, 2017, questions and answers (Q\&A) were published based on Guide No. 04/2015 and RDC No. 53/2015. In 2019, given the difficulties in performing toxicological assessments of degradation products, ANVISA sought assistance from the Management of Safety and Efficacy Assessment (GESEF), which provides guidelines on how to conduct toxicological studies. In July 2019, more Q\&A were published and these focused on the qualification of degradation products. The publication was entitled "Flow of qualification analysis of impurities and degradation products of medicines classified as synthetic and semisynthetic ${ }^{\prime 14,16}$.

In November 2019, ANVISA revoked RE No. 1/2005 and published RDC No. 318/2019, which established the criteria for carrying out stability studies on API and dosage forms, except biological products. This Resolution also addressed photostability studies, in addition to highlighting the importance of using stability indicating methods ${ }^{17}$. 


\section{PARALLEL PUBLISHING BETWEEN ANVISA AND ICH GUIDELINES}

Before the conception of ANVISA in 1999, the ICH had already published the Q3A guidelines on impurities in new drug substances, and the Q3B guidelines on impurities in new drug products in 1995 and 1996, respectively. Ten years later, by 2006, these two guidelines had already been revised twice. Thus, in parallel, ANVISA published the first discussion on the topic of drug stability in 2005 through Guide No. 1/2005 ${ }^{18-20}$.

In 2014, the ICH M7 guideline was published. This was the only guide in the world that specifically dealt with mutagenic impurities. The guide underwent its first revision in 2017, and a second, a year later. ANVISA has recommended the use of this guideline as a reference for mutagenic impurities. Figure 1 shows the evolution of standard regulations in the world and in Brazil over time.

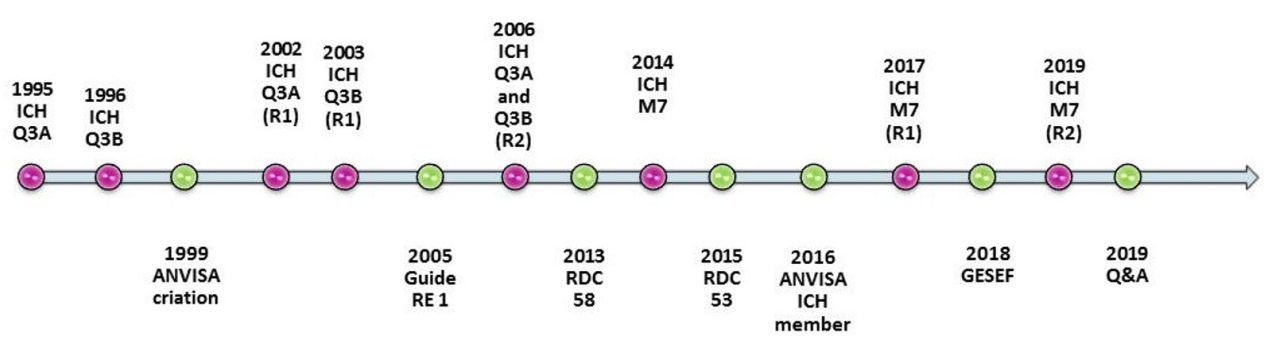

Figure 1 - Parallel chronology of Brazilian and international regulations related to degradation products. Note: green circles: Brazilian regulations; pink circles: international regulations

The publication of RDC No. 53/2015 resulted in some changes to international guidelines. This guide specifically emphasized the parameters of forced degradation studies using metal ions, indicated a target of $10 \%$ degradation of the API, and required that the study be conducted concomitantly with a placebo. In the case of fixed-dose combinations, the guide suggested that the degradation study be carried out individually and in the combined form, among other specifications ${ }^{1}$.

During the aforementioned periods, ANVISA had little time to adapt to the changing requirements of degradation products that were being implemented worldwide. However, today, the scenario is more promising, considering that degradation products are one of the main concerns of the pharmaceutical industry, regulatory bodies, and inspectorates.

\section{IMPURITIES AND DEGRADATION PRODUCTS}

The production of medicines and the synthesis of drug molecules require reactive chemicals, solvents, catalysts, and other substances. Consequently, these processes lead to the formation of impurities in medicinal substances and associated pharmaceutical products $^{18,19}$.

There are different definitions for impurities, as well as how to classify them. According to the definition by ANVISA (2015), an impurity is any substance present in a product that is not the API or an excipient. The ICH's "Q3A Impurities in New Drug Substances" classifies impurities into three groups: organic impurities, inorganic impurities, and residual solvents. Organic impurities can originate with drug production or with the storage process. These impurities include starting materials, by-products, synthetic intermediates and degradation products, reagents, binders, and catalysts. Inorganic impurities are usually known. These include reagents, binders and catalysts, heavy metals or other residual metals, and inorganic salts. Residual solvents are organic or inorganic liquids used to prepare solutions and suspensions during the synthesis of a new active substance ${ }^{18}$.

According to the classification of the Q3A guidelines, the degradation products found in pharmaceutical products are considered organic impurities. In addition to the synthetic 
pathway, degradation products are the result of chemical changes that arise due to improper product storage, light, $\mathrm{pH}$, humidity, and exposure to non-storage temperatures. They can also be caused by characteristics inherent to the drug, reaction with excipients, contact with the primary packaging, and aging of the product itself ${ }^{1,18}$.

\section{STABILITY STUDIES}

The shelf life of a pharmaceutical product is the period in which it maintains its approved quality characteristics as per the manufacturer, within specifications recommended by the law, that is, the deadline for using a certain pharmaceutical product ${ }^{17}$.

The shelf life is therefore based on stability studies, which assess the interference of environmental factors, such as temperature, humidity, light, and others related to the product itself, including the physical and chemical properties of API and excipients, pharmaceutical form and its composition, and manufacturing processes, in addition to providing adequate storage conditions $\mathbf{s}^{1,17}$.

In Brazil, stability studies as recommended by ANVISA through RDC No. 318/2019 must incorporate the following three components: (a) an accelerated stability study, which evaluates possible physical, chemical, and microbiological changes in API or drugs, under forced storage conditions; (b) a follow-up stability study, which monitors and confirms the validity period for medication or API and the API Retest Term; and (c) a long-term stability study that verifies the physical, chemical, and microbiological characteristics of API or a medication under proposed storage conditions for the stated validity period. These results can be used to define the API retest period.

The analytical conditions of the stability studies (Table 1) should be in accordance with the climatic zones of the country that requires the registration. Brazil is classified as a IVB climatic zone, designated for countries with hot and humid climates ${ }^{17}$.

Table 1 - Analytical conditions and justifications for each stability study

\begin{tabular}{|c|c|c|c|c|c|}
\hline $\begin{array}{l}\text { Stability } \\
\text { Study }\end{array}$ & $\begin{array}{l}\text { Temperature and } \\
\text { humidity }\end{array}$ & $\begin{array}{l}\text { Storage } \\
\text { condition }\end{array}$ & Time & Main goals & Main purposes \\
\hline Accelerated & $\begin{array}{c}40^{\circ} \mathrm{C} \pm 2^{\circ} \mathrm{C} / \\
75 \% \mathrm{RH} \pm 5 \% \mathrm{RH}\end{array}$ & Forced & 6 months & $\begin{array}{l}\text { Determine } \\
\text { provisional shelf } \\
\text { life and storage } \\
\text { conditions }\end{array}$ & $\begin{array}{c}\text { Product } \\
\text { development; } \\
\text { registration } \\
\text { documentation }\end{array}$ \\
\hline Long Term & $\begin{array}{c}30^{\circ} \mathrm{C} \pm 2^{\circ} \mathrm{C} / \\
75 \% \mathrm{RH} \pm 5 \% \mathrm{RH}\end{array}$ & $\begin{array}{l}\text { Room } \\
\text { temperature }\end{array}$ & 24 months & $\begin{array}{c}\text { Prove validity and } \\
\text { storage conditions } \\
\text { by the accelerated } \\
\text { study }\end{array}$ & $\begin{array}{c}\text { Registration } \\
\text { documentation }\end{array}$ \\
\hline Follow-up & $\begin{array}{c}30^{\circ} \mathrm{C} \pm 2^{\circ} \mathrm{C} / \\
75 \% \mathrm{RH} \pm 5 \% \mathrm{RH}\end{array}$ & $\begin{array}{c}\text { Room } \\
\text { temperature }\end{array}$ & $\begin{array}{l}\text { From } 6 \text { to } \\
24 \text { months }\end{array}$ & $\begin{array}{l}\text { Check for changes } \\
\text { in formulation or } \\
\text { manufacturing } \\
\text { process that affect } \\
\text { stability }\end{array}$ & $\begin{array}{l}\text { Quality assurance } \\
\text { / quality control }\end{array}$ \\
\hline
\end{tabular}

RH: Relative Humidity

According to ANVISA, in order to obtain the registration of a drug, it is mandatory that the accelerated stability study is completed, the long-term study is in progress, and that the follow-up study is already designed to commence as soon as the long-term study is over. For a long-term study, a period of 24 months can be extended if necessary, and in practice can reach up to 36 months ${ }^{17}$.

The granting of a provisional validity period through the results of an accelerated stability study is possible, as this study empirically demonstrates what happens to a product stored for a long period of time. However, these results must be later confirmed by performing a long-term study as the results of accelerated studies are not consistent in predicting physical changes ${ }^{17}$. 


\section{REPORTING, IDENTIFICATION AND QUALIFICATION OF DEGRADATION PRODUCTS}

According to RDC No. 53/2015, the reporting, identification, and qualification thresholds for degradation products are associated with the maximum daily dose of the studied substance. The reporting limit is the value above which a degradation product must be reported. Above this threshold, it becomes necessary to report the presence of the impurity, but not its chemical structure. According to Table 2, a substance with a maximum daily dose of $1 \mathrm{~g}$ has an impurity reporting limit of $0.1 \%$. Impurities with concentrations above this value must be reported to regulatory agencies. The identification limit is the value above which a degradation product must have its chemical structure identified and reported. In this case, it will be necessary to use equipment such as a mass spectrometer capable of identifying molecule structures. The qualification threshold is the concentration above which a degradation product must be qualified, identified, and reported. Qualification tests provide proof of the safety of the degradation product, often through toxicological tests ${ }^{1,2}$.

These criteria are applied to the results found at the end of a stability study, however, they can serve as a reference for the stability indicating analytical method, after forced degradation studies (Table 2).

Table 2 - Reporting, identification, and qualification thresholds for degradation products

\begin{tabular}{ccc}
\hline Thresholds & Maximum Daily Dose & Thresholds for Degradation Products \\
\hline Reporting threshold & $\leq 1 \mathrm{~g}$ & $0.1 \%$ \\
& $>1 \mathrm{~g}$ & $0.5 \%$ \\
& $<1 \mathrm{mg}$ & $1.0 \%$ ou $5 \mu \mathrm{g}$ TDI, whichever is lower \\
Identification threshold & $1 \mathrm{mg}-10 \mathrm{mg}$ & $0.5 \%$ ou $20 \mu \mathrm{g}$ TDI, whichever is lower \\
& $>10 \mathrm{mg}-2 \mathrm{~g}$ & $0.2 \%$ ou $2 \mathrm{mg}$ TDI, whichever is lower \\
& $>2 \mathrm{~g}$ & $0.10 \%$ \\
& $<10 \mathrm{mg}$ & $1.0 \%$ ou $50 \mu \mathrm{g}$ TDI, whichever is lower \\
Qualification threshold & $10 \mathrm{mg}-100 \mathrm{mg}$ & $0.5 \%$ ou $200 \mu \mathrm{g}$ TDI, whichever is lower \\
& $>100 \mathrm{mg}-2 \mathrm{~g}$ & $0.2 \%$ ou $3 \mathrm{mg}$ TDI, whichever is lower \\
& $>2 \mathrm{~g}$ & $0.15 \%$ \\
\hline
\end{tabular}

TDI: Total Daily Intake

\section{FORCED DEGRADATION STUDIES}

Apart from determining the shelf life and storage conditions of new drug products, stability studies are also carried out with the aim of ensuring the chemical, physical, microbiological, therapeutic, and toxicological integrity of the drug and the pharmaceutical dosage form within specified limits, to prove the safety and efficacy of the medicine ${ }^{21}$.

In terms of efficacy, the first effect that generally occurs due to drug product instability is a decrease in potency. However, if the degradation products formed are toxic, their accumulation is as important, or more than, the decrease in potency ${ }^{22}$.

The stability study method for degradation products is developed and validated with the intention that it will be able to detect all real degradation products, that is, those found during long-term stability testing of the product. Nevertheless, it becomes a very arduous task to develop this method only with samples obtained at the end of the stability study, as degradation is generally mild ${ }^{2}$.

Thus, the study of forced degradation/stress in drugs and medications, is different from the study of accelerated stability, as it uses more extreme conditions. According to RDC No. 53/2015, pharmaceutical companies must conduct stress studies on API, placebo, and finished product after exposing them to thermal, humid, acidic, basic, oxidation, photolytic, and metal ion conditions s $^{1,23}$.

These harsh conditions intentionally cause greater degradation in comparison to stability studies, in addition to ensuring greater specificity of the method, since it intensifies the accurate separation of the API from the degradants. For this reason, stress studies are used as a tool for the development 
of a stability indicating method ${ }^{2}$. In addition, stress studies provide information on the degradation pathway and the potential products that can be formed during storage. Ideally, these studies should be conducted during the research and development phase, as they can facilitate the development of formulations, production of the drug, and the choice of packaging 24,25 . However, following the implementation of RDC No. 53/2015, it became mandatory in the application for registration and post-registration of drug products, for pharmaceutical companies to perform a critical analysis of the degradation pathway following stress studies and provide their results.

Although the experimental procedures for all conditions are not mandatory due to the different inherent characteristics of drug molecules, it is acceptable to technically justify not performing assessments at certain parameters during forced degradation studies ${ }^{1}$.

Forced degradation studies therefore, challenge the analytical method, and are expected to produce possible degradation products, if any. On the contrary, stability studies challenge the product, and are performed under realistic conditions. Degradation products are therefore not desirable during the latter analyses.

\section{STEPS IN CONDUCTING FORCED DEGRADATION STUDIES}

\subsection{Bibliographic research}

Forced degradation studies begin with previous bibliographic research using scientific databases, available official compendiums, direct searches, and, if possible, the Drug Master File (DMF). These documents can provide essential information related to the physical and chemical characteristics of the drug and its degradation products, such as pKa, solubility, molecular weight, molecular structure, degradation routes, and impurity profile. In particular, the DMF outlines the chemical composition of the API, its route of synthesis, stability profile, purity and impurity profile, packaging data, and the information on degradation studies carried out by the manufacturer ${ }^{26}$.

This research will be crucial to evaluate the analytical methods already developed and any toxicity alerts. With information on the composition of the formulation, it is also possible to investigate whether there are any possible interactions between the API and excipients that generate degradation products over time. The collection of all information is extremely important and will serve as the basis for planning the stress studies and ultimately the development of a stability indicating method ${ }^{26}$.

\subsection{Conducting experimental forced degradation tests}

The studies should be conducted using a laboratory, pilot, or industrial scale batch of the drug, and it is recommended that the same degradation conditions be used for the placebo, the pharmaceutical ingredient, in addition to the finished formulation for comparison purposes. RDC No. 53/2015 suggests that the study be applied to all strengths of the drug available in the market ${ }^{1}$.

It is recommended to obtain API degradation of at least $10 \%$ of the main peak. This ensures that the degradation is neither too mild nor a generation of second order degradation products (products originating from already degraded substances) ${ }^{1}$.

The presence of degradation products will be the basis for the development and validation of a stability indicating method and the critical analysis of the degradation profile of the drug. The development of this method should include peak purity verification of the API chromatogram in the dosage form and evaluate the factors that may interfere in the stability of the medication ${ }^{1}$.

\subsection{Acid and base hydrolysis}

Hydrolysis is the most common reaction that leads to the formation of degradation products over a wide pH range. This reaction is more frequent in liquid dosage forms, since 
water is one of the main catalysts for chemical reactions. Different $\mathrm{pH}$ values must be evaluated to check the instability of the drug, as the presence of hydrogen and hydroxyl ions can accelerate or slow down the degradation process ${ }^{4,27}$. Liquid dosage forms tend to have a shorter shelf life than solid dosage forms, even after formulation and storage interventions that aim to ensure the efficacy and stability of the final pharmaceutical form. Nonetheless, solid dosage forms are not exempt from undergoing hydrolysis, as they may be susceptible to different environmental humidity, considering a country as extensive as Brazil. For these studies, it is recommended to use sodium hydroxide and hydrochloric acid between $0.01 \mathrm{~N}$ and $1 \mathrm{~N}$ at different exposure times ${ }^{4,27}$.

\subsection{Oxidation}

Oxidation involves the transfer of an electron to create charged molecules, viz. anions and cations. This reaction can occur in a chain under the influence of molecular oxygen, called auto-oxidation. The most susceptible organic functional groups are amines, sulfides, and phenols, leading to the formation of $\mathrm{N}$-oxides, hydroxylamines, sulfones, and sulfoxides. Other functional groups in the presence of labile hydrogen atoms are prone to oxidation ${ }^{4,27}$.

Drugs in a solid state hardly undergo oxidation, although numerous potential oxidative pathways are present in the formulation. Excipients contain impurities that are capable of initiating oxidation, such as organic hydroperoxides, which are generally found in excipients such as polysorbate 80 , polyethylene glycol (PEG) 400, hydroxypropylmethylcellulose (HPMC), and polyvinylpyrrolidone (PVP) ${ }^{28}$.

The most widely used reagent to force oxidative degradation is hydrogen peroxide $\left(\mathrm{H}_{2} \mathrm{O}_{2}\right)$. In addition, azobisisobutyronitrile (AIBN) has been widely used. It is recommended to use $\mathrm{H}_{2} \mathrm{O}_{2}$ at room temperature (unstable at high temperatures) in concentrations between $0.1 \%$ and $3.0 \%$, with $0.3 \%$ being quite common. Normally, the exposure time is $24 \mathrm{~h}$, and can be extended up to $72 \mathrm{~h}^{4}$.

\subsection{Photodegradation}

Ultraviolet (UV) or fluorescent light has the ability to initiate the formation of primary drug degradation products in exposed dosage forms. The photodegradation test works on the principle of investigating the effects of intensity and exposure to light on the physical and chemical properties of the analyzed drugs. Molecules that have chromophore groups are activated photochemically by UV or visible radiation. This change in the molecule can be quite harmful, interfering with its therapeutic effect, or worse, generating phototoxicity 3,29.

The photodegradation test is the only one that has clear parameters of execution, which are described in the Q1B guidelines. The medication and the drug must be subjected to a minimum of 1.2 million lux-h and $200 \mathrm{~W} / \mathrm{m}^{2}$ of light, with the accepted wavelength being in the range of 300 to $800 \mathrm{~nm}$ to cause photolytic degradation. The maximum recommended exposure is 6 million lux-h for up to four days. The test can also be conducted via exposure to sunlight, with degradation products being monitored over four days ${ }^{4,30}$.

\subsection{Thermal degradation}

The rise in temperature accelerates the rate of chemical reaction, increasing the levels of degradation of the substances. The ICH Q1A guideline recommends that thermal exposure be done at temperatures above those used in the accelerated stability study of $40^{\circ} \mathrm{C}$ and $75 \%$ $\mathrm{RH}$. It is suggested that the temperature be raised every $10^{\circ} \mathrm{C}$ during the study. For solid products, it is recommended to use dry (oven) and wet heat at $75 \% \mathrm{RH}$. Connors et al. recommended the use of a climatic chamber or desiccator with saturated saline solution for tests in humid heat ${ }^{4,31}$. 


\subsection{Metal ions}

Degradation using metal ions is a mandatory test in Brazil as outlined in RDC No. 53/2015', since the addition of metal ions into solutions containing the drug can be used to assess possible oxidation of the molecule. According to Guide No. 4 of $2015^{2}$, iron (III) or copper (II) solutions are generally used. However, Baertschi et al. ${ }^{28}$ demonstrated the relevance of studying degradation pathways using iron (II) or copper (III). There are still differences in the literature regarding the solution to be used for this type of degradation.

In any case, the variations in the concentration of the stressful metallic solution are not considered significant, with $0.05 \mathrm{M}$ being generally used. Nevertheless, variations in sample temperatures are not recommended. The test should be performed only on established parameters and if there is no degradation after one day, the product is considered stable in these conditions ${ }^{28}$.

\section{STABILITY INDICATING METHOD}

According to the FDA, a stability indicating method is a validated quantitative analytical procedure used to detect the stability of drugs and finished products over time. This method must be able to measure changes in drug concentrations without interference from degradation products, impurities, and excipients; that is, it must be selective and specific ${ }^{32}$.

In addition, the method should be developed to detect and quantify the most relevant degradation products. It is quite a complex task to develop the method using only the API or the final drug samples from the stability studies. For this reason, forced degradation studies are carried out, in which the concentrations of degradants are highly expressed. Thus, it is possible to differentiate potential degradation products from the actual degradants ${ }^{2,32}$.

The frequently used instrumentation in method development is the high-performance liquid chromatography (HPLC) coupled with a diode array detector (DAD). If the formed products do not have chromophores, it is necessary to use other detectors, such as fluorescence and mass spectrometric detectors, which enable the detection of the formed products, ensuring method specificity. Orthogonal methods are often employed during these studies $^{33}$

\subsection{Liquid chromatography coupled with mass spectrometry (LC-MS)}

Due to the sensitivity and the range of analyzable components, LC-MS is the technique of choice among all other hyphenated techniques in chromatography. In addition, it has the potential to provide an unambiguous characterization of the structures of most degradation products at low concentrations ${ }^{33}$.

Currently, there are a variety of mass spectrometers available commercially that can be coupled with liquid chromatography. They vary according to the source of ionization, and some of their most common techniques include electrospray ionization (ESI), chemical ionization by atmospheric pressure $(\mathrm{APCl})$, and photoionization by atmospheric pressure (APPI). As for mass analyzers, the best known are: quadrupole, ion trap (IonTrap), time of flight (TOF), and orbitrap ${ }^{33}$.

The successful elucidation of the structures of the components is achieved by obtaining the mass-to-charge ratio $(\mathrm{m} / \mathrm{z})$ of the drug by generating protonated $\left([\mathrm{M}+\mathrm{H}]^{+}\right)$or deprotonated $\left([\mathrm{M}-\mathrm{H}]^{-}\right)$molecular ions (adducts are not desirable, but they can happen), followed by obtaining the spectrum of API fragments and its related substances. The precise and exact determination of its mass, elementary formula, presence of a ring or double bonds, number of nitrogen atoms, and study of fragmentation pathways can also be determined, among other properties ${ }^{33}$. Consequently, mass spectrometry coupled with liquid chromatography, mainly with a high-resolution mass analyzer, such as the LC-MS-QTOF, is a tool that provides precious information for the identification of unknown substances, through providing $\mathrm{m} / \mathrm{z}$ with high accuracy ${ }^{4}$. 


\section{PEAK PURITY}

According to RDC No. 166/2017, chromatographic purity is the absence of interference in the chromatogram of the analyte. Peak purity is the spectral homogeneity of a chromatographic peak, indicative of its chromatographic purity. The criteria for concluding whether there is spectral homogeneity and the parameters adopted for the calculation of purity are established by the software used or by means of scientifically based technical evaluations ${ }^{34}$.

Peak purity is an indication that interferents are absent, that is, that two peaks may not overlap. During the development of a stability indicating method, a number of impurities that are generated need to be separated. The intention of determining peak purity is to demonstrate the absence of coelution during analysis. However, it is necessary to consider that in the case of enantiomers or isomers, this differentiation cannot be achieved by peak purity ${ }^{35}$.

Peak purity determination is closely related to the methodology used in determining peak identity, in which two or more overlapping peaks are distinguished. This approach uses the DAD technology or photodiode-array compatible with reverse phase chromatography, which is extensively used in drug analysis. One way to determine peak purity is to evaluate the purity angle value, which must be less than the purity threshold. This is based on comparisons between spectra obtained from the peak analyzed in a defined ultraviolet-visible (UV-VIS) range ${ }^{35}$.

RDC No. 53/2015 requires that the peak purity be determined only for the chromatogram of the API. However, the test is usually performed with the impurities present to ensure that unwanted coelutions do not occur ${ }^{1}$.

\section{MASS BALANCE}

Conceptually, mass balance is the sum of the content and levels of degradation products found to assess their proximity to $100 \%$ of the initial content value, taking into account the margin of precision and analytical accuracy. This definition is based on the ICH Q1A guidelines. However, it is known that the concept of mass balance is very useful for data evaluation, but is not always feasible in practice ${ }^{2,36}$.

The calculation can be performed by using the absolute or relative mass balance formulae. The absolute formula subtracts the sum of the percentage of drug degradation plus the percentage of degradation products formed from $100 \%$. For relative mass balance, the percentage of degradation products formed is divided by the percentage of drug degradation, and the result is multiplied by $100 \%{ }^{36}$.

One of the main reasons for deviations in mass balance is sample preparation. Another point to be considered is the difference in the molar absorptivity of the degradation products generated in relation to the API. In practice, it will often be necessary to perform a manual integration of the peak, to the detriment of the automatic one, to achieve mass balance ${ }^{36}$.

\section{CONSIDERATIONS}

This review addresses a topic relevant to patient safety, as it discusses the regulatory and control aspects of impurities in health technology products. Characterization of the impurity profile for a substance, and development of indicative stability methods are essential criteria for compliance with current legislation, and address a legitimate health concern. As this matter falls under the purview of recently published regulation, many doubts remain regarding methods of conducting studies of forced degradation, and development of methods indicative of stability. Lack of guidance regarding analytical-specific information is another difficulty currently faced by those proposing necessary stress conditions. For this reason, the dissemination of relevant knowledge is of fundamental importance to professionals in the field, to provide sound scientific support for methods development. 
Currently, researchers can use Guide 4, a Question and Answer resource, and RDC 53/2015 as guidance tools. The references used as international guides in the field of degradation product analyses are ICH Q1A, stability testing of new drug substances and products, ICH Q1B, photostability testing of new drug substances and products, ICH Q2B, validation of analytical procedures: methodology, ICH Q3A, impurities in new drug substances, ICH Q3B, impurities in new products, and ICH M7, assessment and control of DNA reactive (mutagenic) impurities in pharmaceuticals to limit potential carcinogenic risk.

\section{CONCLUSION}

Conducting stress studies using only the API or the final drug sample from stability studies is an arduous task. The potential degradation products formed during forced degradation studies may or may not occur during the product's shelf life. The sooner forced degradation studies are carried out in the drug development process, the more information will be obtained about the stability of the considered molecule. Thus, the generation of relevant degradation products during stress studies can assist in the development of a stability indicating method, providing information regarding the drug's degradation route, and also the selection of appropriate storage conditions. Different characteristics of molecules must be taken into account during the establishment of study protocols. Although RDC 53/2015 outlines the parameters of degradation, the analytical conditions are not specified, as well as in other international standards. A well-designed forced degradation study is key to obtaining a good stability indicating method.

\section{ACKNOWLEDGEMENTS}

We would like to thank Editage (www.editage.com) for English language editing.

\section{REFERENCES}

1. Brasil. RDC $n^{\circ}$ 53, de 4 de dezembro de 2015. Estabelece parâmetros para a notificação, identificação e qualificação de produtos de degradação em medicamentos com substâncias ativas sintéticas e semissintéticas, classificados como novos, genéricos e similares, e dá outras providências. Diário Oficial da União; Brasília; 2015.

2. Agência Nacional De Vigilância Sanitária. Medicamentos- Guia $n^{\circ}$ 4, versão 1, de 04 de dezembro de 2015. Guia para obtenção do perfil de degradação, e identificação e qualificação de produtos de degradação em medicamentos [Internet]. Brasília: ANVISA; 2015 [cited 2018 Feb 17]. p. 1-22. Available from:

http://portal.anvisa.gov.br/documents/10181/2738062/Perfil+e+produtos+de+degradação+em+me dicamentos.pdf/c18a4857-9a5c-4292-a1bf-07af6cad6902?version=1.01 bf-07af6cad6902

3. Sengupta P, Chatterjee B, Tekade RK. Current regulatory requirements and practical approaches for stability analysis of pharmaceutical products: a comprehensive review. Int J Pharm. 2018;543(12):328-44. http://dx.doi.org/10.1016/j.ijpharm.2018.04.007. PMid:29635054.

4. Blessy M, Patel RD, Prajapati PN, Agrawal YK. Development of forced degradation and stability indicating studies of drugs - A review. J Pharm Anal. 2014;4(3):159-65. http://dx.doi.org/10.1016/j.jpha.2013.09.003. PMid:29403878.

5. Melo SRO, Homem-de-Mello M, Silveira D, Simeoni LA. Advice on degradation products in pharmaceuticals: a toxicological evaluation. PDA J Pharm Sci Technol. 2014;68(3):221-38. http://dx.doi.org/10.5731/pdajpst.2014.00974. PMid:25188345.

6. Johnston A, Holt DW. Substandard drugs: a potential crisis for public health. Br J Clin Pharmacol. 2014;78(2):218-43. http://dx.doi.org/10.1111/bcp.12298. PMid:24286459.

7. Borges LG, Fröehlich PE. Thalidomide: new perspectives for its use as antiinflammatory, immunossupressive and antiangiogenic drug. Rev Assoc Med Bras. 2003;49(1):96-102. http://dx.doi.org/10.1590/S0104-42302003000100041. PMid:12724820.

8. Agência Nacional de Vigilância Sanitária. Talidomida [Internet]. Brasília: ANVISA; 2019 [cited 2019 May 15]. Available from: http://portal.anvisa.gov.br/talidomida 
9. Gross JM. Fanconi syndrome (adult type) developing secondary to the ingestion of outdated tetracycline. Ann Intern Med. 1963;58(3):523-8. http://dx.doi.org/10.7326/0003-4819-58-3-523. PMid:13950771.

10. Pena A, Carmona A, Barbosa A, Lino C, Silveira I, Castillo B. Determination of tetracycline and its major degradation products by liquid chromatography with fluorescence detection. J Pharm Biomed Anal. 1998;18(4-5):839-45. http://dx.doi.org/10.1016/S0731-7085(98)00268-4. PMid:9919986.

11. Food and Drug Administration. Information Paper on L-tryptophan and 5-hydroxy-L-tryptophan [Internet]. Rome: FDA; 2001 [cited 2019 Aug 25]. Available from: http://www.nemsn.org/Articles/FDA-Info.pdf

12. Blossom DB, et al. Outbreak of adverse reactions associated with contaminated heparin. $\mathrm{N}$ Engl J Med. 2008;359(25):2674-84. http://dx.doi.org/10.1056/NEJMoa0806450. PMid:19052120.

13. Agência Nacional de Vigilância Sanitária. Esclarecimento quanto a presença de impurezas em medicamentos para hipertensão arterial [Internet]. Brasília: ANVISA; 2019 [cited 2019 Jun 15]. Available from: http://portal.anvisa.gov.br/documents/219201/4340788/Sartanas+Portal_+07-052019+\%28003\%29.pdf/bf14105c-136b-47e5-b94e-161b0e659e73

14. Agência Nacional de Vigilância Sanitária. Roteiro de Análise de Eficácia e Segurança para Avaliação de Registro de Medicamento Sintético [Internet]. Brasília: ANVISA- GESEF; 2019 [cited 2019 Oct 26]. Available from: file:///C:/Users/ffarias/Downloads/Roteiro de Análise de Eficácia e Segurança para Avaliação de Registro de Medicamento Sintético.pdf

15. Brasil. RDC ${ }^{\circ}{ }^{\circ}$ 58, de 20 de dezembro de 2013. Estabelece parâmetros para a notificação, identificação e qualificação de produtos de degradação em medicamentos com substâncias ativas sintéticas e semissintéticas, classificados como novos, genéricos e similares, e dá outras providências. Diário Oficial da União; Brasília; 2013. Seção 1; p. 127.

16. Agência Nacional de Vigilância Sanitária. Perguntas e Respostas. Assunto : Fluxo de análise de qualificação de impurezas e produtos de degradação de medicamentos classificados como sintéticos e semissintéticos [Internet]. Brasília: ANVISA; 2019 [cited 2019 Oct 15]. p. 24. Available from: http://portal.anvisa.gov.br/documents/33836/418522/Perguntas+e+Respostas++qualificação+de+impurezas/34fbde77-57aa-44d9-a1f5-f01b4fb36284

17. Brasil. RDC n 318, de 6 de novembro de 2019. Estabelece os critérios para a realização de Estudos de Estabilidade de insumos farmacêuticos ativos e medicamentos, exceto biológicos, e dá outras providências. Diário Oficial da União; Brasília; 2019.

18. International Conference on Harmonisation. Impurities in New Drug Substances Q3A (R2). ICH Harmon Tripart Guidel. ICH; 2006; p. 118-22.

19. International Conference on Harmonisation. Impurities in New Drug Products Q3B(R2). ICH Harmon Tripart Guidel. ICH; 2006. p. 1-16.

20. Brasil. Ministério da Saúde. RE n¹, de 29 de julho de 2005. Guia para a Realização de Estudos de Estabilidade. Diário Oficial da União; Brasília; 2005.

21. Allen LVJ, Popovich NG, Ansel HC. Formas farmacêuticas e sistemas de liberação de fármacos. 9. ed. Porto Alegre: Artmed; 2013. 716 p.

22. Kommanaboyina B, Rhodes CT. Trends in stability testing, with emphasis on stability during distribution and storage. Drug Dev Ind Pharm. 1999;25(7):857-68. http://dx.doi.org/10.1081/DDC100102246. PMid:10459490.

23. Alcântara FC, Rescia VC, Santos MA, Valduga CJ, Justina Valduga C. Testes de degradação forçada para fármacos e medicamentos. Rev Pesqui e Inovação Farm. 2013;5(1):38-48.

24. Reynolds DW, Facchine KL, Mullaney JF, Alsante KM, Hatajik TD, Motto MG. Conducting forced degradation studies. Pharm Technol. 2002;26(2):48-56.

25. Musmade DS, Shinde PS, Ajage RK, Aher SJ, Ware AL, Patil PP. A Review on Stress Testing of Drug Substances and Drug Product. Inven Rapid Pharm Process Dev. 2012;2013(1):1-11.

26. Da Costa GN, Viana GM, Lima UF Fo, Cabral LM. Diretrizes para elaboração de um protocolo e relatório de estudo de degradação forçada de medicamentos de acordo com a RDC 53/2015. Infarma - Ciências Farm. 2018;30(3):194-202. 
27. Silva KER, Alves LDS, Soares MFR, Passos RCS, Faria AR, Rolim Neto PJ. Modelos de avaliação da estabilidade de fármacos e medicamentos para a indústria farmacêutica. Rev Cienc Farm Basica Apl. 2009;30(2):1-8.

28. Baertschi SW, Alsante KM, Reed R. Pharmaceutical stress testing: predicting drug degradation. 2nd ed. London: Informa Healthcare; 2011. 624 p.

29. Kleinman MH, Smith MD, Kurali E, Kleinpeter S, Jiang K, Zhang Y, Kennedy-Gabb SA, Lynch AM, Geddes CD. An evaluation of chemical photoreactivity and the relationship to phototoxicity. Regul Toxicol Pharmacol. 2010;58(2):224-32. http://dx.doi.org/10.1016/j.yrtph.2010.06.013. PMid:20600453.

30. International Conference on Harmonisation. ICH Q1B Photostability testing of new active substances and medicinal products [Internet]. London: European Medicines Agency; 1998. p. 1-9. Available from: http://www.ema.europa.eu/docs/en_GB/document_library/Scientific_guideline/2009/09/WC500002647.pdf

31. Connors KA, Amidon GL, Stella VJ. Chemical stability of pharmaceuticals: a handbook for pharmacists. 2nd ed. New York: John Wiley \& Sons; 1986. 864 p.

32. Food and Drug Administration. Analytical Procedures and Methods Validation for Drugs and Biologics. Guid Ind [Internet]. Rome: FDA; 2015 [cited 2019 Oct 15]. Available from: https://www.fda.gov/downloads/drugs/guidances/ucm386366.pdf

33. Narayanam M, Handa T, Sharma P, Jhajra S, Muthe PK, Dappili PK, Shah RP, Singh S. Critical practical aspects in the application of liquid chromatography-mass spectrometric studies for the characterization of impurities and degradation products. J Pharm Biomed Anal. 2014;87:191-217. http://dx.doi.org/10.1016/j.jpba.2013.04.027. PMid:23706957.

34. Brasil. RDC $n^{\circ} 166$, de 24 de julho de 2017. Dispõe sobre a validação de métodos analíticos e dá outras providências. Diário Oficial da União; Brasília; 2017.

35. Castledine JB, Fell AF. Strategies for peak-purity assessment in liquid chromatography. J Pharm Biomed Anal. 1993;11(1):1-13. http://dx.doi.org/10.1016/0731-7085(93)80143-O. PMid:8466954.

36. International Conference on Harmonisation. Guidance for Industry. Q1A(R2) Stability Testing of New Drug Substances and Products. ICH; 2003. p. 1-22.

\section{Authors' contributions}

Study design and planning: FFF, EP. Data collection, analysis and interpretation: FFF, VAPM, HMY, LMT. Manuscript preparation or revision: FFF, VAPM, HMY, LMT, EP. All authors approved the final version of the manuscript and assume public responsibility for its content. 